\title{
Institutions and Foreign Direct Investment: Evidence from Sub-Saharan Africa Regions
}

\author{
John Mayanja Bbale ${ }^{1} \&$ John Bosco Nnyanzi ${ }^{2}$ \\ ${ }^{1}$ Department of Policy and Development Economics, Makerere University Kampala, Uganda \\ ${ }^{2}$ Department of Economic Theory and Analysis, Makerere University Kampala, Uganda \\ Correspondence: John Bosco Nnyanzi, Department of Economic Theory and Analysis, Makerere University \\ Kampala, Uganda. E-mail: jbnnyanzi@yahoo.com
}

\author{
Received: May 30, 2016 Accepted: June 8, 2016 Online Published: July 30, 2016 \\ doi:10.5539/jsd.v9n4p11 URL: http://dx.doi.org/10.5539/jsd.v9n4p11
}

\begin{abstract}
The paper set out to investigate the nexus between institutional quality and inward FDI and how the presence of liberalization and financial development influence this linkage. We build on Dunning's eclectic paradigm that focuses on locational advantages. A fixed effects approach is employed and the estimation results confirm the crucial role of institutional quality in attracting FDI inflows. However the impact varies with the particular group. In particular, apart from SADC, institutional quality seems to matter significantly in all the other groups especially in EAC and ECOWAS. Additional findings reveal a mixed impact regarding the presence of financial development and liberalization in the institution-FDI nexus: While Trade liberalization policies seem to be at the forefront in ECOWAS and SADC groups, it is credit depth and capital account openness that appear to matter most in EAC. We confirm the resilience of inward FDI during the global crisis and document a positive significant relationship between FDI inflows on the one hand and host market size and infrastructure development on the other. While a one-size-fits-all-policy should be discouraged due to the heterogeneous nature of SSA countries, overall, a comprehensive set of policies designed with caution to improve the institutional quality, the financial system, trade openness and capital account liberalization would be valuable for attracting FDI inflows to SSA.
\end{abstract}

Keywords: eclectic paradigm, financial development, FDI inflows, institutions, integration, liberalization, SSA

\section{Introduction}

Many African countries have for the last two decades prioritized the provision of reforms in line with tax, institutions, trade, market, infrastructure and finance in the hope that they can attract inward FDI as an engine of economic growth (e.g. Abdulla et al. 2012; United Nations, 2010). Despite these reforms inward FDI to the region has remained low in comparison to fellow developing countries. Given the theoretical growth-enhancing role of FDI, a captivating question that continues to bother policy makers and economists alike is: What more should be done to attract inward FDI to Africa? Empirical evidence with regard to the key determinants of the same has remained mixed, suggestive of the need for a further deeper analysis into the drivers of FDI inflows to host countries.

In the current paper, we endeavor to answer these questions focusing on four groups of countries from Sub-Saharan Africa (SSA) involved in regional economic cooperation - the East African Community (EAC), the Southern African Development Cooperation (SADC), the Economic Cooperation of West African States (ECOWAS), and the Economic Community of Central African States (ECCAS). The fundamental argument underlying our analysis is that FDI inflows play a pivotal role in the stability of regional integration and therefore any quantifiable analysis of what influences FDI inflows is timely. Moreover we are cognizant of the heterogeneous nature of countries and regions. The relevance of investigating the drivers of inward FDI is not unambiguous. According to the World Investment Report (2014), in Africa, FDI inflows increased only by 4\% to $\$ 57$ billion in 2013, a reflection of a minimal 3.9 percentage share in world inward FDI. This increase is very small in comparison to Latin America and the Caribbean that contributed $20.1 \%$ of world inward FDI in the same year.

In light of the above considerations, it is important to analyze the relevant drivers of inward FDI that have consistently remained low in Africa. We contribute to this on-going discussion by examining the role of 
institutions in explaining FDI inflows to SSA over the period 1996-2013. In support of the institutional argument, theory purports that FDI is elastic to transaction costs of investments that may delay production. By implication countries characterized by high corruption rates, continuous wars and strikes, disrespect of the rule of law and macroeconomic instabilities are likely be less attractive to FDI inflows compared to those with a stable macroeconomic and institutional environment. However if a country harbors plenty of natural resources such as oil and gas, there is likelihood that whether such a country has good or bad institutions it may attract enormous inward FDI. We purport that institutions might behave differently in the presence of liberalization and financial development depending on the region under analysis.

More specifically, we address three questions: First, do institutions matter for FDI inflows to SSA? Second, what is the individual effect of liberalization and financial development on inward FDI? Third, what is the impact of trade and capital account liberalization and financial development on the dynamics of the FDI inflows and institutions relationship? In investigating these issues we prefer a more comprehensive analysis that takes into account the heterogeneous nature of countries and regions. Our study is related to Anyanwu (2011), who generally analyzes the determinants of inward FDI using a panel of seven five-year non-overlapping windows for the period 1980-2007. Different from his paper, we argue that the impact of institutions on inward FDI might depend on the presence financial development, capital account as well as trade liberalization. Our focus is on Sub-Saharan Africa and her sub-regional groupings in order to avoid considering the entire Africa as one homogeneous group. Consequently, we contribute to literature by considering regional differences of the effect of institutions on the FDI inflows in SSA. The estimation results from our model appear to produce mixed evidence partly in support of the significant and positive role of institutions in reinforcing FDI inflows but this appears to be dependent on the sub-regional grouping under consideration.

The study is deemed significant to many countries in SSA that are struggling to design policies to attract FDI inflows but also timely and informative as it offers a detailed quantifiable analysis of the role of government institutions, hence contributing to the scanty literature in the area. African countries in particular can no longer afford to exist without economic interdependence. Policies to promote FDI inflows are handy in achieving the benefits of globalization and this underscores the spillover effects from FDI inflows into poverty reduction, sustainable economic growth and development that are still much wanting in the groups under study. Focus on factors that are unique to these countries is likely to lead to relevant policies for the region.

The rest of the paper is organized as follows: section 2 reviews the theoretical and empirical literature of FDI inflows while section 3 provides the methodology. The empirical results and conclusions are presented in sections 4 and 5 , respectively.

\section{Related Literature}

North (1990) asserts that institutions affect economic activities through transaction and production costs. To maximize profits, investors are willing to invest their capital in countries that minimize the transaction costs of doing business. These costs may be minimized when markets are integrated at the national and international level with institutions playing a big role. Relatedly, according to the eclectic theory of FDI developed by Dunning, $(1977,1988)$ a firm has to meet three preconditions to successfully engage in international activity and these include: Ownership advantages such as scale economies and better technologies; Locational advantages such as policy, economic and institutional factors; and, Internalization advantages that are associated with protecting the proprietary assets of foreign firms from being replicated by other competing firms, especially domestic firms.

On the other hand, the theoretical underpinning of the FDI and financial development relationship hinges on the argument that the development of the local financial sector allows foreign firms to borrow in order to increase their innovative activities in the host country. By implication, better developed financial sectors in the host country are likely to assist in influencing FDI and contribute to the generation of positive impacts such as technological diffusion, efficiency and skill acquisition (Alfaro et. al., 2004). It is not illogical that financial sectors impact on investment financing and business activities, implying that an improvement in the efficiency of local financial systems is likely to promote production activities and the attraction of more FDI inflows. A negative relationship between FDI inflows and the bank credit may however not be dismissible and it would imply either an abundance of domestic capital such that foreign capital in the form of FDI would not be needed in the hosting countries or that there is an inverse relationship between FDI and other types of flows, mainly bank loans (Anyanwu, 2011).

In another strand of literature, the likes of Kose et al. (2003) suggest that countries can attract international capital flows by de-regulating activities in their domestic financial markets, and liberalizing their capital account 
transactions and equity markets. To this effect the removal or relaxation of restrictions on foreign ownership limitations can increase FDI inflows just as the de-regulation of offshore borrowing may attract more foreign private loan inflows through the removal of quantitative restrictions on overseas borrowing and the provision of tax incentives. On the other hand, countries which allow goods and services to freely cross their borders are more likely to attract more FDI inflows compared to those countries that employ restrictive and protective policies (Ang, 2008). However, a parallel argument that trade liberalization might reduce market-seeking inward FDI due to changing costs of trade and other factors is likewise logical.

In the current paper we argue that any possible linkage between institutions and inward FDI might be facilitated or aggravated by liberalization or financial development. Analyzing this nexus is particularly relevant for countries in the SSA which still grapple with policies to do with institutional quality, liberalization and financial development for purposes of increasing inward FDI to their regions. We add to the inconclusive debate by looking at the regional economic integration blocs in SSA, since it is likely that what drives FDI inflows might vary by region given the heterogeneity of African countries.

In addition to the above theoretical justification, a number of empirical studies have examined the determinants of FDI inflows to host countries. Some have used cross-country data to document a positive relationship between institutions and FDI inflows including inter alia Asiedu (2006), Ourvashi (2012), and, Gani (2007). The latter, in particular, using a panel for 164 countries over the period 1996-2006, provide evidence that one standard deviation change in institutional quality improves FDI inflows by a factor of 1.69. On the other hand, a recent study by Kim (2010) documents evidence in support of the argument that countries with high level of corruption of government and low level of democracy have higher FDI inflows while being lower for those with greater political rights. Still others such as Onyeiwu and Hemanta (2004) find no significant relationship between the quality of institutions and inward FDI.

Regarding the impact of liberalization on inward FDI, the results from the existing literature are as well far from consensus. In Asiedu (2006), for example, the effect of the three types of capital control policies on FDI inflows varies depending on the period and region. She is backed by Ghosh et al. (2012) where the impact of FDI restrictions on inward FDI stocks in the 23 OECD countries is found to be positively significant with an estimated short-run elasticity that lies in the range between -0.06 to -0.14 , whereas the corresponding long-run elasticity is in the range between -0.64 to -1.49 (see also Leitao, 2010). However, Butkiewicz and Yanikkaya (2008) argue that the trade-FDI linkage might be facilitated by institutions such as political stability and corruption in a host country. The latter is nonetheless silent on the possibility that the institution- FDI nexus would depend on trade. Additionally, another strand of literature such as Noy and $\mathrm{Vu}$ (2007), find no impact of capital account liberalization on FDI inflows.

Another strand of literature while a positive linkage can be traced in Kinda (2010) and Anyanwu (2011), Desbordes and Wei (2012) find that whereas the source countries' financial development tends to contribute strongly to the promotion of FDI especially on sectors that are typically dependent on external finance, destination countries' financial development matter much less and may, in sectors not typically dependent on external finance, even have a negative impact on FDI. Most of these studies also include control variables such as infrastructure, market size, and inflation.

Overall, the existing literature remains mixed on the impact of institutions, liberalization, and financial development on inward FDI. We bridge the gap by investigating the extent to which FDI inflows could (or could not) be influenced by these variables in question. To our knowledge, no study has looked at the possible linkage between these variables, and FDI inflows using a sample that takes into account heterogeneity. We focus on individual SSA groupings to avoid irrelevant policies that would accrue out of a study that assumes all developing countries to be homogeneous.

\section{Empirical model and Data}

\subsection{Empirical Model}

In order to examine the impact of institutions on inward FDI to SSA and the trio regional groupings, we use the following model that is based on Dunning's $(1977,1988)$ theoretical framework which groups micro- and macro-level determinants in order to analyze why and where multinational companies (MNCs) invest abroad:

$$
F D I_{i t}=\beta_{0}+\beta^{\prime} I N S T N_{i t}+\vartheta^{\prime} X_{i t}+\eta_{i}+\varepsilon_{i t}
$$

where FDI stands for foreign direct investment while government institutions are represented by $I N S T N_{i t} \beta_{0}$ is the constant term while $\beta^{\prime}$ and $\vartheta^{\prime}$ stand for the parameters of $I N S T N_{i t}$ and control variables $X_{i t}$ to be 
estimated, respectively. Included in $X_{i t}$ are infrastructure development, market size, and macroeconomic instability as control variables known in empirical literature to affect FDI inflows.

We are fully aware that due to agglomeration effect, the current FDI would likely depend on the past levels of FDI inflows. On this basis we introduce an FDI inflow lagged variable. Equation (1) then becomes:

$$
F D I_{i t}=F D I_{t-1}+\beta^{\prime} I N S T N_{i t}+\vartheta^{\prime} X_{i t}+\eta_{i}+\varepsilon_{i t}
$$

In addition, two important variables of interest in the study are liberalization (captured by capital account and trade liberalization) and bank credit to the private sector. We include each independently and then as interactions with institutions in the model. The estimation model then becomes:

$$
F D I_{i t}=\alpha F D I_{t-1}+\beta^{\prime} I N S T N_{i t}+\varphi^{\prime} L^{\prime} B_{i t}+\theta I N S T N_{i t} * L^{\prime} B_{i t}+\vartheta^{\prime} X_{i t}+\eta_{i}+\varepsilon_{i t}
$$

where $\operatorname{INSTN}_{i t} * \operatorname{LIB}_{i t}$ is the interaction term showing the indirect effect of government institutions on FDI inflows via liberalization.

Differentiating equation (3) with respect to first, institutional quality, and second, to liberalization, shows the partial effects of government institutions and liberalization on inward

FDI as computed as follows:

$$
\begin{gathered}
\frac{\partial F D I_{i t}}{\partial I N S T N_{i t}}=\beta^{\prime}+\theta^{\prime} L I B_{i t} \\
\frac{\partial F D I_{i t}}{\partial L I B_{i t}}=\varphi^{\prime}+\theta^{\prime} I N S T N_{i t}
\end{gathered}
$$

Equation (4) is the marginal impact of institutional indicators on inward FDI when liberalization is included in the model specification. If $\theta^{\prime}<0$, and the absolute value exceeds $\beta^{\prime}>0$ then equation (4) implies that a one percentage point increase in institutional quality yields a negative impact on inward FDI as liberalization improves. Similarly, our interpretation of equation (5) follows that of (4).

Next, we examine the impact of institutions on inward FDI in the presence of financial development.

$$
F D I_{i t}=\alpha F D I_{t-1}+\beta^{\prime} \operatorname{INSTN}_{i t}+\varpi^{\prime} F I N_{i t}+\operatorname{\theta INSTN}_{i t} * F I N_{i t}+\vartheta^{\prime} X_{i t}+\eta_{i}+\varepsilon_{i t}
$$

where, $\operatorname{INSTN}_{i t} * F I N_{i t}$ is the interaction term reflecting the indirect impact of institutions on FDI via financial development.

$$
\begin{aligned}
& \frac{\partial F D I_{i t}}{\partial I N S T N_{i t}}=\beta^{\prime}+\theta^{\prime} F I N_{i t} \\
& \frac{\partial F D I_{i t}}{\partial F I N_{i t}}=\varpi^{\prime}+\theta^{\prime} I N S T N_{i t}
\end{aligned}
$$

Equations (7) and (8) are interpreted as in equations (5) and (6) above.

All our panel regressions are based on the fixed effects estimator with country fixed effects and robust standard errors. It should be noted that the presence of the lagged dependent variable $F D I_{i t-l}$ makes our estimating model dynamic and would necessitate the application of dynamic estimating techniques if the problem of autocorrelation is to be minimized. Given that in all our sample and subsamples the number of observations (N) is greater that the time period (T), the GMM (generalized method of moments) estimators designed for short time-dimension (small-T) and large-N (observations) panels would be appropriate. The more efficient and precise estimator would be the system GMM proposed by Blundell and Bond (1998) which combines both regressions in differences and in levels as instruments for the variables. However, the disadvantage with the system GMM is that it uses too many instruments, making the Hansen test p-values too large. In order to control the number of instruments one would collapse the GMM-style instruments in the system GMM regressions to keep the number of instruments smaller than the number of groups (countries). However collapsing reduces statistical efficiency of panel GMM regressions (Roodman, 2009a, 2009b). On the other hand, although we recognize that GMM estimators are, under appropriate assumptions, asymptotically unbiased (when $\mathrm{N}$ tends to infinity and $\mathrm{T}$ is finite), the fact that they make use of an instrumental variables technique to avoid the dynamic panel data bias often leads to poor small sample properties. Apart from the possibility of suffering from a substantial finite sample bias due to weak instrument problems (see e.g. Bun and Kiviet 2006; Bun and Windmeijer 2010), Monte Carlo simulations show that the GMM estimators have a relatively large standard 
deviation compared to the FE estimator (see e.g. Arellano and Bond 1991). Given the foregone disadvantage of GMM in relation to our subsamples, we zero down to the Fixed Effects modeling technique. However, as noted by Baltagi (2001), when lagged values of the dependent variable are used as explanatory variables, the fixed-effects estimator is consistent only to the extent that the time dimension of the panel (T) is large. Therefore, two other methods that allow estimation in the presence of $\operatorname{AR}(1)$ autocorrelation within cross-sectional correlation and heteroskedasticity across panels are applied as robustness checks and for comparison purposes with previous studies that have made use of the same (e.g. Anyanwu, 2011). These are the robust pooled ordinary least squares (OLS) and the robust maximum likelihood optimization of the generalized linear model (GLM). Due to limited space and the similarity of the results from all these techniques, we only present the baseline results from FE estimator.

\subsection{Data}

The study uses a panel of 44 countries from SSA over the period 1996-2013 (see Table 15 for a list of countries). Focus is on four regional groupings from SSA - EAC, ECOWAS, ECCAS and SADC. Data on institutions is obtained from the World Government Indicators constructed by Kaufmann et al. (2011), using a model of unobserved components based on information gathered through a wide variety of cross-country surveys as well as polls of experts and are presented in the form of scores that lies between -2.5 and 2.5, with higher scores corresponding to better outcomes for the quality of institutions. We use an average of the six indicators - voice and accountability (voice acc), regulatory quality (reg qlty), corruption control (corr_contr), government effectiveness (gov_eff), rule of law (rule_law), and political stability (pol_stab) - to capture institutions (see Table 2). It is expected that poor institutional quality decreases FDI inflows.

The second part consists of the data on capital account liberalization obtained from Chinn and Ito up-dated index of financial openness to 2013 (Chinn-Ito, 2006). The index measures a country's degree of capital account openness (KAOPEN), based on the binary dummy variables that codify the tabulation of restrictions on cross-border financial transactions reported in the IMF's Annual Report on Exchange Arrangements and Exchange Restrictions (AREAER). Also, as is customary in the growth and finance literature, we use the domestic credit allocated to the private sector by banks and other financial intermediaries, normalized by GDP, to proxy financial development.

We use GDP annual growth to capture market size. In a further test for agglomeration effects, we relate current inward FDI to the past FDI inflows and other explanatory variables as in Anyanwu (2011). Macroeconomic instability is captured by inflation whereas infrastructure development is proxied by the number of fixed telephone lines or gross fixed capital formation. All variables except institutions are logged to reduce skewness. In addition, the dependent variable is lagged once to take cognizance of the view that FDI decisions may be made based on historical data. Tables 1 and 2 display the descriptive statistics of the explanatory variables and the variable definitions.

Table 1. Descriptive statistics

\begin{tabular}{lllllllllll}
\hline & SSA & & ECOWAS & \multicolumn{3}{c}{ EAC } & \multicolumn{3}{c}{ SADC } & \multicolumn{3}{c}{ ECCAS } \\
\hline & Mean & Std. Dev. & Mean & Std. & Mean & Std. & Mean & Std. Dev. & Mean & Std. \\
\hline Infdi & 5.2223 & 11.3128 & 4.8601 & 12.6320 & 1.8461 & 1.9116 & 5.1809 & 6.9346 & 8.9187 & 19.3007 \\
Intrade & 4.2341 & 0.5197 & 4.1376 & 0.3321 & 3.7236 & 0.2672 & 4.5005 & 0.4374 & 4.4427 & 0.6810 \\
Incred & 2.5028 & 0.9017 & 2.3552 & 0.7087 & 2.5544 & 0.5789 & 2.8828 & 1.0972 & 1.8372 & 0.5225 \\
lnpop & 15.8390 & 1.4326 & 15.9835 & 1.1316 & 16.7793 & 0.7125 & 15.5183 & 1.7331 & 15.0778 & 1.1517 \\
lntel100 & -0.0991 & 1.3771 & -0.3742 & 0.8624 & -0.9207 & 0.5673 & 0.6570 & 1.8042 & -0.5218 & 1.2424 \\
gdp_gro & 5.1627 & 9.0495 & 5.2414 & 8.8118 & 5.4652 & 3.3778 & 4.2191 & 4.7012 & 7.3325 & 17.9820 \\
infl_cpi & 18.1943 & 160.5006 & 6.7048 & 8.2560 & 9.1185 & 6.0851 & 41.4688 & 281.0967 & 3.2921 & 3.7782 \\
instn & -0.6470 & 0.6052 & -0.7147 & 0.4570 & -0.7854 & 0.4086 & -0.2989 & 0.7339 & -0.9893 & 0.3416 \\
kaopen & -0.7026 & 1.1823 & -0.7271 & 1.2487 & -0.1005 & 1.4937 & -0.5709 & 1.2579 & -1.1877 & 0.0000 \\
lnGFCF_gdp & 2.9030 & 0.5951 & 2.7178 & 0.5996 & 2.8871 & 0.4609 & 2.8991 & 0.5384 & 3.2037 & 0.7136 \\
\hline
\end{tabular}

Note: Std. Dev. is standard deviation; SSA is Sub-Saharan Africa; ECOWAS is Economic Community of West African States; EAC is East Africanmunity; SADC is Southern Africa Development Corporation; and, ECCAS is Economic Community of Central African States. 
Table 2. Definition of variables, measurement and data sources

\begin{tabular}{|c|c|c|}
\hline Variable & Definition & Data Sources \\
\hline $\operatorname{lnfdi}$ & Foreign direct investment, net inflows ( $\%$ of GDP) - in logs. & WDI \\
\hline lncredit & Domestic credit to the private sector ( $\%$ of GDP). & WDI \\
\hline lngdp_grow & $\begin{array}{l}\text { It is a logged annual percentage growth rate of GDP at market prices based } \\
\text { on constant local currency. }\end{array}$ & WDI \\
\hline lnpop & Total population (logged) - The values shown are midyear estimates. & WDI \\
\hline Intel100 & Fixed and mobile phone subscribers (per 1,000 people) - in logs. & WDI \\
\hline lnGFCF_gdp & $\begin{array}{l}\text { Gross fixed capital formation ( } \% \text { of GDP) - in logs, includes land } \\
\text { improvements, plant, machinery, and the construction of roads, railways, and } \\
\text { the like. }\end{array}$ & WDI \\
\hline lntrade & Trade $(\%$ of GDP $)$ - in logs; it is proxy for trade liberalization & WDI \\
\hline Infl_cpi & Inflation as measured by the consumer price index. & WDI \\
\hline Kaopen & $\begin{array}{l}\text { Capital openness index is scaled in the range between }-2.5 \text { and } 2.5 \text {, with } \\
\text { higher values standing for larger degrees of financial openness. }\end{array}$ & Chinn-Ito \\
\hline voice_acc & $\begin{array}{l}\text { Voice and accountability Index captures the perceptions at which the citizens } \\
\text { participate in selecting their governments, freedom of expression, freedom of } \\
\text { association and a free media. }\end{array}$ & WGI \\
\hline reg_qlty & $\begin{array}{l}\text { Regulatory quality Index captures the ability of the government to formulate } \\
\text { and implement sound policies aimed at promoting the private sector. }\end{array}$ & WGI \\
\hline corr_contr & $\begin{array}{l}\text { Corruption Index measures the extent to which public power is exercised for } \\
\text { private gains. }\end{array}$ & WGI \\
\hline gov_eff & $\begin{array}{l}\text { Government Effectiveness Index measures the quality of public and civil } \\
\text { services and the ability to formulate and implement good policies. }\end{array}$ & WGI \\
\hline rule_law & $\begin{array}{l}\text { Rule of law index captures not only the quality of contract enforcement but } \\
\text { also the likelihood of crime and violence. }\end{array}$ & WGI \\
\hline pol_stab & $\begin{array}{l}\text { Political stability and absence index measures the likelihood that the } \\
\text { government will be destabilized either through domestic violence or } \\
\text { overthrown by unconstitutionally means. }\end{array}$ & WGI \\
\hline Crisis_dum & Dummy variable for Global financial crisis 2007-2009. & \\
\hline
\end{tabular}

\section{Estimation Results}

\subsection{Effect of General Institutions on Inward FDI}

As presented in Table 3, Column 1, the coefficient on institutional quality in SSA is significantly positive at $10 \%$ and economically meaningful. Perhaps its importance could be more visible when it is interacted with liberalization and credit depth. We come back to this issue later. Interestingly, the regional groupings offer a similar picture. For example in EAC, Table 4, Column 1, an improvement in institutional quality by one unit leads to a constant percentage increase of approximately 1.096 in inward FDI. By implication, an increase in institutional quality by one standard deviation is associated with an increase in inward FDI by about 0.27 percentage points $(0.447 * 0.605=0.27)$. The result is not substantially altered when we control for capital account liberalization. Overall, institutions appear to positively and significantly matter for inward FDI in SSA. For the case of EAC, the impact is visibly high at 1\% level of significance as exhibited in Columns 1, 4, 5 and 6, Table 4. Similarly, the ECOWAS grouping demonstrates significant support for the role of good institutions in catalyzing FDI inflows to the region. This significance is in line with the findings in Asiedu (2006). 
Table 3. Effects of institutions and their interactions with credit depth, trade and capital account liberalization on FDI Inflows in SSA

\begin{tabular}{|c|c|c|c|c|c|c|c|}
\hline & (1) & (2) & (3) & (4) & (5) & (6) & (7) \\
\hline \multirow[t]{2}{*}{ L.lnfdi } & $0.274 * * *$ & $0.272 * * *$ & $0.272 * * *$ & $0.268^{* * *}$ & $0.264 * * *$ & $0.274 * * *$ & $0.270 * * *$ \\
\hline & [0.039] & {$[0.040]$} & {$[0.040]$} & [0.037] & {$[0.038]$} & [0.039] & {$[0.040]$} \\
\hline \multirow[t]{2}{*}{$\operatorname{lntel} 100$} & -0.025 & -0.009 & -0.011 & -0.098 & -0.11 & -0.02 & -0.009 \\
\hline & [0.094] & {$[0.091]$} & [0.091] & {$[0.112]$} & {$[0.115]$} & {$[0.096]$} & {$[0.096]$} \\
\hline \multirow[t]{2}{*}{ lnpop } & $0.826^{*}$ & $0.960^{*}$ & $0.933^{*}$ & $0.809^{*}$ & $0.877^{*}$ & $0.831 *$ & $0.785^{*}$ \\
\hline & {$[0.422]$} & [0.489] & {$[0.486]$} & {$[0.446]$} & {$[0.446]$} & {$[0.420]$} & {$[0.423]$} \\
\hline \multirow[t]{2}{*}{ gdp_gro } & -0.001 & -0.001 & -0.001 & $-0.008 * *$ & $-0.008 * *$ & -0.001 & -0.001 \\
\hline & {$[0.006]$} & {$[0.006]$} & {$[0.006]$} & [0.003] & {$[0.003]$} & {$[0.006]$} & {$[0.006]$} \\
\hline \multirow[t]{2}{*}{ infl_cpi } & -0.001 & -0.001 & -0.001 & -0.001 & -0.001 & -0.001 & -0.001 \\
\hline & {$[0.001]$} & {$[0.001]$} & {$[0.001]$} & {$[0.001]$} & {$[0.001]$} & {$[0.001]$} & {$[0.001]$} \\
\hline \multirow[t]{2}{*}{ crisis_dum } & 0.114 & 0.098 & 0.098 & 0.109 & 0.101 & 0.118 & 0.114 \\
\hline & {$[0.076]$} & {$[0.078]$} & {$[0.078]$} & [0.079] & {$[0.078]$} & {$[0.076]$} & {$[0.077]$} \\
\hline \multirow[t]{2}{*}{ lnGFCF_gdp } & $0.832 * * *$ & $0.827 * * *$ & $0.829 * * *$ & $0.752 * * *$ & $0.719 * * *$ & $0.829 * * *$ & $0.823^{* * *}$ \\
\hline & {$[0.152]$} & {$[0.169]$} & [0.168] & [0.165] & [0.168] & {$[0.148]$} & [0.143] \\
\hline \multirow[t]{2}{*}{ instn } & $0.447 *$ & 0.359 & 0.197 & 0.392 & 1.729 & $0.466^{*}$ & $0.622 * *$ \\
\hline & {$[0.230]$} & {$[0.325]$} & {$[0.620]$} & [0.239] & [1.319] & {$[0.234]$} & {$[0.265]$} \\
\hline \multirow[t]{2}{*}{ lncred } & & -0.045 & 0.015 & & & & \\
\hline & & {$[0.131]$} & {$[0.204]$} & & & & \\
\hline \multirow[t]{2}{*}{ ins_cred } & & & 0.061 & & & & \\
\hline & & & {$[0.182]$} & & & & \\
\hline \multirow[t]{2}{*}{ lntrade } & & & & 0.433 & 0.147 & & \\
\hline & & & & {$[0.270]$} & [0.334] & & \\
\hline \multirow[t]{2}{*}{ ins_trad } & & & & & -0.329 & & \\
\hline & & & & & {$[0.300]$} & & \\
\hline \multirow[t]{2}{*}{ kaopen } & & & & & & -0.101 & -0.056 \\
\hline & & & & & & {$[0.076]$} & {$[0.088]$} \\
\hline \multirow[t]{2}{*}{ ins_kaopen } & & & & & & & 0.194 \\
\hline & & & & & & & {$[0.118]$} \\
\hline Observations & 574 & 550 & 550 & 555 & 555 & 573 & 573 \\
\hline
\end{tabular}

Note: Country-fixed effects included; the dependent variable is FDI in the log form; all explanatory variables except gdp_gro and infla_cpi, are in log form; Robust standard errors in brackets; ${ }^{* * *} \mathrm{p}<0.01,{ }^{* *} \mathrm{p}<0.05$ and ${ }^{*}$ $\mathrm{p}<0.1$. 
Table 4. Effects of institutions and their interactions with credit depth, trade and capital account liberalization on FDI Inflows in EAC

\begin{tabular}{|c|c|c|c|c|c|c|c|}
\hline & (1) & (2) & (3) & (4) & (5) & (6) & (7) \\
\hline \multirow[t]{2}{*}{ L.lnfdi } & $0.223 * *$ & $0.212 * *$ & $0.207 * * *$ & $0.227^{* *}$ & $0.180^{* *}$ & $0.214 * *$ & $0.199 * *$ \\
\hline & {$[0.062]$} & {$[0.047]$} & [0.037] & {$[0.058]$} & {$[0.051]$} & {$[0.058]$} & {$[0.063]$} \\
\hline \multirow[t]{2}{*}{$\operatorname{lntel} 100$} & -0.248 & -0.15 & -0.122 & -0.149 & $-0.240 * *$ & -0.195 & -0.214 \\
\hline & [0.304] & [0.199] & {$[0.228]$} & {$[0.328]$} & {$[0.067]$} & {$[0.322]$} & [0.334] \\
\hline \multirow[t]{2}{*}{ lnpop } & -0.369 & $1.259^{*}$ & $2.355^{* *}$ & -0.273 & 1.307 & -0.169 & 0.149 \\
\hline & [1.162] & {$[0.526]$} & [0.699] & {$[1.202]$} & {$[0.756]$} & [1.087] & [1.145] \\
\hline \multirow[t]{2}{*}{ gdp_gro } & 0.012 & 0.021 & 0.011 & 0.021 & $0.027^{*}$ & 0.013 & 0.013 \\
\hline & [0.017] & {$[0.022]$} & {$[0.033]$} & {$[0.022]$} & {$[0.010]$} & {$[0.016]$} & [0.017] \\
\hline \multirow[t]{2}{*}{ infl_cpi } & 0.051 & 0.048 & 0.033 & 0.056 & 0.061 & 0.052 & 0.052 \\
\hline & [0.039] & {$[0.042]$} & {$[0.041]$} & [0.033] & {$[0.037]$} & {$[0.040]$} & [0.041] \\
\hline \multirow[t]{2}{*}{ crisis_dum } & 0.085 & 0.000 & -0.023 & 0.055 & 0.083 & 0.045 & 0.093 \\
\hline & {$[0.273]$} & [0.229] & {$[0.288]$} & [0.267] & {$[0.171]$} & {$[0.288]$} & [0.297] \\
\hline \multirow[t]{2}{*}{ lnGFCF_gdp } & $1.136^{* *}$ & $0.881 * * *$ & 0.322 & $1.490 * * *$ & -0.048 & $1.048^{* *}$ & $0.929 * *$ \\
\hline & {$[0.322]$} & {$[0.179]$} & {$[0.230]$} & [0.269] & {$[0.724]$} & {$[0.270]$} & [0.298] \\
\hline \multirow[t]{2}{*}{ instn } & $1.096 * * *$ & 1.639 & -5.745 & $1.135^{* * *}$ & $19.855^{*}$ & $1.225 * * *$ & $1.582 *$ \\
\hline & {$[0.160]$} & [1.218] & [3.033] & [0.185] & [7.755] & {$[0.266]$} & [0.595] \\
\hline \multirow[t]{2}{*}{ lncred } & & $-0.959 * *$ & 1.069 & & & & \\
\hline & & {$[0.225]$} & {$[0.671]$} & & & & \\
\hline \multirow[t]{2}{*}{ ins_cred } & & & $3.220^{* *}$ & & & & \\
\hline & & & [0.898] & & & & \\
\hline \multirow[t]{2}{*}{ Intrade } & & & & -0.976 & $-4.494 * *$ & & \\
\hline & & & & [1.113] & [1.614] & & \\
\hline \multirow[t]{2}{*}{ ins_trad } & & & & & $-5.057 *$ & & \\
\hline & & & & & [2.076] & & \\
\hline \multirow[t]{2}{*}{ kaopen } & & & & & & -0.195 & -0.018 \\
\hline & & & & & & [0.192] & [0.194] \\
\hline \multirow[t]{2}{*}{ ins_kaopen } & & & & & & & 0.482 \\
\hline & & & & & & & [0.405] \\
\hline Observations & 85 & 77 & 77 & 85 & 85 & 85 & 85 \\
\hline
\end{tabular}

Note: Country-fixed effects included; the dependent variable is FDI in the log form; all explanatory variables except gdp_gro and infla_cpi, are in log form; Robust standard errors in brackets; ${ }^{* * *} \mathrm{p}<0.01,{ }^{* *} \mathrm{p}<0.05$ and $*$ $\mathrm{p}<0.1$.

On the other hand, there is little evidence to confirm the importance of institutional quality to inward FDI in the SADC group. Perhaps other factors might offer a better explanation as to what drives inward FDI to these regions. We come back to this issue later on. Surprisingly, there is an economically meaningful negative sign on the relevant coefficient in Column 1, Table 6. However, the finding is in line with other strand of literature that records a deleterious role of institutional quality in inward FDI (e.g. Kim, 2010). One possible explanation for this inverse relationship lies in the existence of the highly needed but scarce natural resources such as precious metals that justify the risk undertaken by investors in these regions. However, with the inclusion of trade control variable and its interaction with institutions in Column 5, the institution coefficient turns out to be positive, though still insignificant at any statistical level, but economically in support of the importance of improving the institutional environment for purposes of attracting FDI inflows. 
Table 5. Effects of institutions and their interactions with credit depth, trade and capital account liberalization on FDI inflows in ECOWAS

\begin{tabular}{|c|c|c|c|c|c|c|c|}
\hline & (1) & (2) & (3) & (4) & (5) & (6) & $(7)$ \\
\hline \multirow[t]{2}{*}{ L.lnfdi } & $0.347 * * *$ & $0.337 * * *$ & $0.330 * * *$ & $0.304 * * *$ & $0.307 * * *$ & $0.341 * * *$ & $0.327 * * *$ \\
\hline & {$[0.076]$} & {$[0.068]$} & {$[0.076]$} & [0.080] & {$[0.080]$} & [0.069] & {$[0.072]$} \\
\hline \multirow[t]{2}{*}{ Intel100 } & 0.079 & 0.091 & 0.155 & 0.241 & 0.258 & 0.124 & 0.132 \\
\hline & {$[0.238]$} & {$[0.224]$} & {$[0.213]$} & {$[0.265]$} & {$[0.245]$} & [0.239] & {$[0.236]$} \\
\hline \multirow[t]{2}{*}{ lnpop } & 1.469 & 1.229 & 1.428 & 0.977 & 1.119 & 1.386 & 1.248 \\
\hline & {$[0.876]$} & [1.101] & {$[1.077]$} & [0.899] & {$[0.832]$} & {$[0.821]$} & {$[0.786]$} \\
\hline \multirow[t]{2}{*}{ gdp_gro } & -0.019 & -0.017 & $-0.013 *$ & -0.023 & -0.022 & -0.02 & -0.01 \\
\hline & {$[0.011]$} & {$[0.011]$} & {$[0.007]$} & {$[0.014]$} & {$[0.015]$} & {$[0.011]$} & {$[0.006]$} \\
\hline \multirow[t]{2}{*}{ infl_cpi } & 0.02 & 0.019 & 0.018 & 0.022 & 0.022 & $0.023^{*}$ & $0.023^{*}$ \\
\hline & {$[0.013]$} & {$[0.013]$} & {$[0.014]$} & {$[0.016]$} & {$[0.016]$} & {$[0.013]$} & {$[0.012]$} \\
\hline \multirow[t]{2}{*}{ crisis dum } & 0.027 & 0.022 & 0.02 & 0.03 & -0.046 & 0.051 & 0.059 \\
\hline & [0.117] & {$[0.117]$} & {$[0.125]$} & {$[0.146]$} & {$[0.135]$} & {$[0.127]$} & [0.123] \\
\hline \multirow[t]{2}{*}{ lnGFCF_gdp } & $0.518^{*}$ & 0.472 & 0.495 & $0.649^{*}$ & $0.706^{* *}$ & $0.494 *$ & $0.504 *$ \\
\hline & {$[0.271]$} & {$[0.276]$} & {$[0.283]$} & {$[0.364]$} & {$[0.308]$} & {$[0.253]$} & {$[0.252]$} \\
\hline \multirow[t]{2}{*}{ instn } & $0.836^{* *}$ & $0.825^{* *}$ & $2.406^{* *}$ & $0.741^{*}$ & $6.812^{*}$ & $0.813^{* *}$ & $1.188^{* * *}$ \\
\hline & {$[0.364]$} & {$[0.376]$} & {$[0.936]$} & [0.417] & {$[3.240]$} & {$[0.357]$} & {$[0.181]$} \\
\hline \multirow[t]{2}{*}{ lncred } & & 0.159 & -0.415 & & & & \\
\hline & & {$[0.216]$} & {$[0.451]$} & & & & \\
\hline \multirow[t]{2}{*}{ ins_cred } & & & -0.621 & & & & \\
\hline & & & {$[0.361]$} & & & & \\
\hline \multirow[t]{2}{*}{ lntrade } & & & & 0.364 & -0.773 & & \\
\hline & & & & {$[0.507]$} & {$[0.803]$} & & \\
\hline \multirow[t]{2}{*}{ ins_trad } & & & & & $-1.426^{*}$ & & \\
\hline & & & & & {$[0.702]$} & & \\
\hline \multirow[t]{2}{*}{ kaopen } & & & & & & $-0.506 * *$ & -0.103 \\
\hline & & & & & & {$[0.190]$} & {$[0.165]$} \\
\hline ins kaopen & & & & & & & $\begin{array}{l}0.560 * * * \\
{[0.130]}\end{array}$ \\
\hline Observations & 195 & 195 & 195 & 178 & 178 & 195 & 195 \\
\hline
\end{tabular}

Note: Country-fixed effects included; the dependent variable is FDI in the log form; all explanatory variables except gdp_gro and infla_cpi, are in log form; Robust standard errors in brackets; *** $\mathrm{p}<0.01,{ }^{*} \mathrm{p}<0.05$ and $*$ $\mathrm{p}<0.1$.

\subsection{Effect of Liberalization on Inward FDI}

Another variable of central interest in the study is liberalization, examined in a two-fold manner, first as capital account openness and second as trade liberalization. Mixed results appear dominate our findings. Regarding SSA in general, the economic interpretation of the positive sign in Column 4, Table 3, would imply that trade openness is potentially beneficial to inward FDI though the relevant coefficient is not significant at any conventional level. By intuition, the coefficient on trade is supportive of the argument that it pays for countries to remove trade restrictions if they want to attract inward FDI. This is similarly the case for the SADC sub-region as exhibited in Column 4, Table 6. Here we observe a positive and statistically significant coefficient at 10 percent conventional level. By implication, on average a $1 \%$ increase in trade openness is likely to lead to $0.814 \%$ increase in inward FDI to SADC region. Augmenting the outcome is the results in Column 4, Table 5, where an increase in trade openness in ECOWAS by one percent is likely to drive inward FDI by about 0.364 percentage points. 
Table 6. Effects of institutions and their interactions with credit depth, trade and capital account liberalization on FDI inflows in SADC

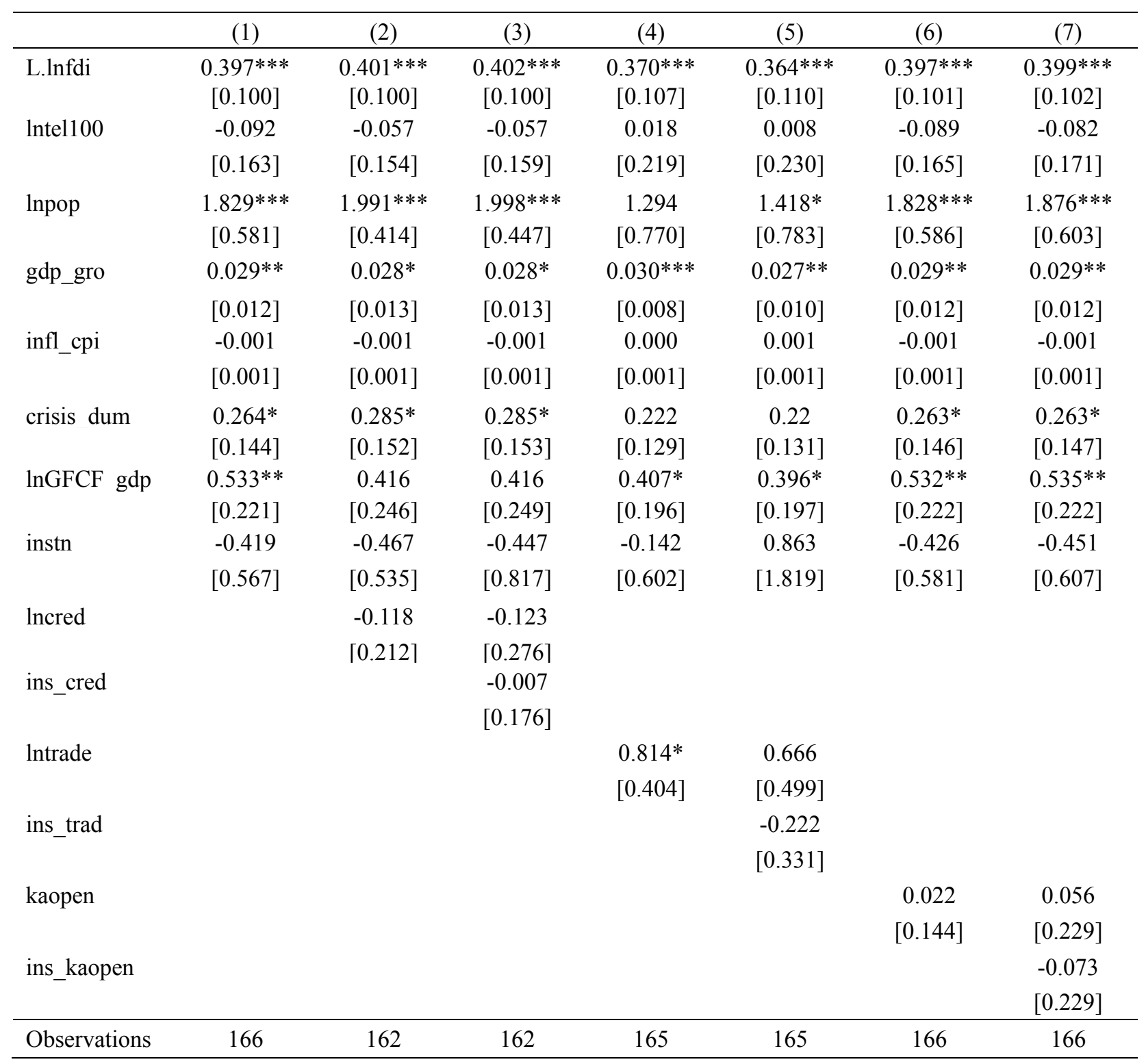

Note: Country-fixed effects included; the dependent variable is FDI in the log form; all explanatory variables except gdp_gro and infla_cpi, are in log form; Robust standard errors in brackets; ${ }^{* * *} \mathrm{p}<0.01,{ }^{* *} \mathrm{p}<0.05$ and ${ }^{*}$ $\mathrm{p}<0.1$.

Perhaps many MNCs that go to the developing countries (e.g. SSA, ECOWAS and SADC) are mainly export oriented. Otherwise the result is consistent with the theory of FDI that supports opening up the country's borders to access the world markets for cheap raw materials. The findings are similar to those of Asiedu (2006). However we fail to find evidence that the removal of trade barriers is significantly helpful in inward FDI in the region apart from SADC regional groupings though the possibility cannot be dismissed since the relevant coefficients are economically meaningful. Surprisingly, for the EAC group, we observe a negative relationship between trade liberalization and inward FDI, as exhibited in Column 4, Table 4. This appears contrary to previous findings (e.g. Asiedu, 2002). However, it is likely that for market-seeking FDI inflows the tariff jumping theory (Mundell, 1957) which argues that MNEs that seek to serve local markets may decide to set up subsidiaries in the host country when it is difficult for them to import products in that country, would explain the observed substitution tendency between trade and FDI (see Anyanwu, 2012; Grünfeld and Svindal, 2000).

On the other hand, capital account liberalization does not appear to be an important channel of inward FDI to 
SSA except to her SADC regional grouping. Going by the sign of the relevant coefficient in Column 6, Table 3, one economic interpretation might be that the removal of capital account restrictions is potentially detrimental to inward FDI to the region. When we unbundle SSA into groups, it becomes clearer that countries which employ capital account liberalization policies are unlikely to attract inward FDI. For the case of the EAC group, the evidence in Column 6, Table 4, shows the relevant coefficient negative but not significant at any conventional level. Such deleterious role of capital account liberalization regains significance in the ECOWAS regression in Column 6, Table 5. Specifically, in this column, an increase in capital account openness by one standard deviation is associated with a decrease in inward FDI by about 0.368 percentage points. By implication, capital account liberalization might not necessarily be a catalyst for FDI inflows to these regions. Our finding of no effect of the removal of capital controls on FDI inflows is in line with Asiedu and Lien, (2004) and Asiedu 2006 who documents mixed results including the inverse linkage between liberalization and inward FDI. However, the results of the SADC group in Table 5, Column 6, reiterate the argument that countries which engage in removing FDI restrictions for example, are potentially likely to enjoy an increased inflow of FDI. The relevant sign in this regression is economically meaningful though it lacks significance at any statistical level but equally uncommon in literature (see Noy and $\mathrm{Vu}, 2007$ ). In essence, the observation of a positive linkage between capital account liberalization and the ratio of FDI to GDP highlighted above would support the argument that countries in the SADC region are likely to rely on capital account liberalization to attract inward FDI.

\subsection{Effect of Financial Development on FDI Inflows}

The overall results for SSA seem to suggest a negative nexus between the financial development and inward FDI as evident in Table 3, Column 2, where the relevant coefficient on credit is insignificantly negative. Similar results appear in SADC and ECCAS groups as evident in Column 2, Table 6, and Column 2, Table 7 respectively. One outstanding region that appears to be less dependent on financial depth as a channel for inward FDI is the EAC. Here, the relevant coefficient is negative and statistical significance at 5 percent conventional level as observed in Specification 2, Table 4. Specifically, a 1 percent improvement in financial development appears to discourage inward FDI by about 0.959 percentage points. Intuitionally, credit depth inhibits inward FDI to these regions, a finding contrary to our expectation, though not uncommon in empirical literature (e.g. Fernandez-Arias and Hausmann, 2000). The negative sign would imply that either there is an abundance of domestic capital such that foreign capital in the form of FDI would not be needed in the hosting countries or that there is an inverse relationship between FDI and other types of flows, mainly bank loans. However, in an earlier study by Dasgupta and Ratha (2000), the complementary relationship between FDI flows and Bank loans appears to be present with a lag of one year, though the regression coefficients are found to lack statistical significance, implying that substitution is equally likely. Going by the sign of the relevant coefficient, however, the result for the ECOWAS group in Column 2, Table 5, appears to be in support of the positive role that domestic credit plays in driving inward FDI. 
Table 7. Effects of institutions and their interactions with credit depth, trade and capital account liberalization on FDI inflows

\begin{tabular}{|c|c|c|c|c|c|c|c|}
\hline & $(1)$ & (2) & (3) & (4) & $(5)$ & $(6)$ & $(7)$ \\
\hline \multirow[t]{2}{*}{ L.lnfdi } & 0.109 & 0.108 & 0.113 & 0.161 & 0.139 & 0.109 & 0.109 \\
\hline & {$[0.167]$} & {$[0.167]$} & {$[0.162]$} & {$[0.158]$} & {$[0.148]$} & {$[0.167]$} & {$[0.167]$} \\
\hline \multirow[t]{2}{*}{ Intel100 } & -0.05 & -0.053 & -0.093 & -0.171 & -0.173 & -0.05 & -0.05 \\
\hline & {$[0.061]$} & {$[0.064]$} & {$[0.158]$} & [0.209] & {$[0.220]$} & {$[0.061]$} & [0.061] \\
\hline \multirow[t]{2}{*}{ lnpop } & 0.103 & 0.201 & 0.067 & -0.181 & -0.453 & 0.103 & 0.103 \\
\hline & [0.833] & {$[0.806]$} & {$[0.737]$} & {$[0.773]$} & {$[0.747]$} & {$[0.833]$} & [0.833] \\
\hline \multirow[t]{2}{*}{ gdp_gro } & -0.001 & -0.001 & -0.002 & -0.005 & -0.006 & -0.001 & -0.001 \\
\hline & {$[0.010]$} & {$[0.010]$} & {$[0.010]$} & {$[0.005]$} & {$[0.005]$} & {$[0.010]$} & {$[0.010]$} \\
\hline \multirow[t]{2}{*}{ infl_cpi } & 0.032 & 0.032 & 0.033 & 0.022 & 0.018 & 0.032 & 0.032 \\
\hline & [0.021] & {$[0.022]$} & {$[0.022]$} & {$[0.028]$} & {$[0.031]$} & {$[0.021]$} & {$[0.021]$} \\
\hline \multirow[t]{2}{*}{ crisis_dum } & 0.08 & 0.064 & 0.081 & 0.039 & 0.043 & 0.08 & 0.08 \\
\hline & {$[0.254]$} & [0.239] & {$[0.270]$} & {$[0.175]$} & {$[0.172]$} & {$[0.254]$} & {$[0.254]$} \\
\hline \multirow[t]{2}{*}{ lnGFCF gdp } & $1.260 * * *$ & $1.282 * * *$ & $1.245 * * *$ & $1.596^{*}$ & $1.619^{*}$ & $1.260 * * *$ & $1.260 * * *$ \\
\hline & {$[0.234]$} & {$[0.242]$} & [0.292] & {$[0.724]$} & {$[0.744]$} & {$[0.234]$} & [0.234] \\
\hline \multirow[t]{2}{*}{ instn } & 0.941 & 0.961 & -0.392 & -0.181 & -7.063 & 0.941 & \\
\hline & [0.899] & {$[0.935]$} & [3.624] & [1.064] & [7.854] & [0.899] & \\
\hline \multirow[t]{2}{*}{ lncred } & & -0.065 & 0.711 & & & & \\
\hline & & {$[0.127]$} & [2.152] & & & & \\
\hline \multirow[t]{2}{*}{ ins_cred } & & & 0.671 & & & & \\
\hline & & & [1.799] & & & & \\
\hline \multirow[t]{2}{*}{ lntrade } & & & & -0.883 & 0.969 & & \\
\hline & & & & [0.993] & [2.828] & & \\
\hline \multirow[t]{2}{*}{ ins_trad } & & & & & 1.605 & & \\
\hline & & & & & {$[1.826]$} & & \\
\hline \multirow[t]{2}{*}{ ins_kaopen } & & & & & & & -0.792 \\
\hline & & & & & & & {$[0.757]$} \\
\hline Observations & 81 & 81 & 81 & 80 & 80 & 81 & 81 \\
\hline
\end{tabular}

Note: Country-fixed effects included; the dependent variable is FDI in the log form; all explanatory variables except gdp_gro and infla_cpi, are in log form; Robust standard errors in brackets; ${ }^{* * *} \mathrm{p}<0.01,{ }^{* *} \mathrm{p}<0.05$ and $*$ $\mathrm{p}<0.1$.

\subsection{Effect of Institutions via Liberalization and Financial Development}

The central focus of our paper is the institution-FDI linkage and the overall result confirms our earlier hypothesis of a positive nexus between the two, as evident in SSA, the EAC and ECOWAS groups. But what drives this outcome? In Table 4, Column 3, it appears that the role of institutional quality in FDI inflows to the EAC is dependent on the level of financial development. Going by the total marginal impact of -1.459 [i.e. $1.069+3.22(-0.7854)]$, the presence of greater credit depth appears to divert the positive contribution of good institutional quality to FDI inflows.

Paradoxically, in the presence of liberalization, the interaction effect appears to depend on the type of liberalization. While the total marginal impact of trade liberalization is -1.222 [i.e.-4.494-5.507(-0.647)], implying a reducing role of trade openness as institutions improve to affect positively inward FDI, the effect of capital account liberalization as institutions increase is -0.329 . It can therefore be said for EAC group, capital account openness plays a more negative role than trade openness in influencing inward FDI as institutional 
quality improves. For the ECOWAS group in Table 5, Column 3, institutional quality has a positive relationship with inward FDI and capital account liberalization diverts that impact while trade openness facilitates it. The outcome confirms our earlier hypothesis that the role of institutional quality in determining inward FDI depends partly on the level of trade openness. Still in the same group, the interaction effect of financial development on inward FDI at the institutional quality mean of -0.71 is 0.028 . Intuitively, the presence of an improved financial system is likely to contribute positively to the role good institutional quality plays in attracting inward FDI to the region. When it comes to the SADC group, however, both trade and capital account liberalization seem to facilitate the role of institutional quality in driving inward FDI to the region. The total marginal impacts are respectively 0.2462 and 0.0778 , implying a much stronger supportive role of trade than capital account liberalization in this linkage. On the other hand, the contribution of institution to inward FDI in SADC countries appear to be less forthcoming from financial development as we observe in Table 6, Columns 3, where the total marginal impact is -0.102 [i.e. $-0.123-0.07(-0.299)]$.

\subsection{Additional Findings}

In all specifications, the estimated coefficient of lagged FDI is positive and highly significant at $1 \%$ statistical level, an indication that agglomeration effects are very strong in determining FDI inflows. The decision to invest in a country or region could highly depend on the presence or absence of old investors. For, it seems investors feel much secure coming to a country where other foreign investors already exist in order to minimize on uncertainties. A similar finding is documented in Anyanwu (2011) who argues that the presence of other existing inward FDI provides a good signal of favorable investment climate. In addition, there is a positive coefficient on the population variable, implying that increasing population is plays a key role in influencing FDI inflows as it is likely to be reflective of the market availability especially for market-seeking FDI. Similarly, the relevant coefficient on GDP growth is positive and statistically significant in EAC (e.g. Column 5, Table 4), SADC (e.g. Column 1-7, Table 6) - re-emphasizing the importance of market size as a channel of FDI inflows. However, an unexpected negative linkage is also noticeable (e.g. ECOWAS - see Column 3, Table 5).

Regarding infrastructure development in SSA, the result in Table 3, Columns 5 shows that a one standard deviation increase in in the share of gross fixed capital formation drives the ratio of inward FDI to GDP in the positive direction by about 2.41 percentage points at $1 \%$ statistical level of significance, a finding in line with Asiedu (2006). The positive result is consistently similar for all regional groupings in our analysis. In essence, many MNCs are likely to consider infrastructure development in the host country before they invest there. Also, consistent with the previous studies, inflation is found to play a deleterious role in inward FDI, pointing to the crucial role macroeconomic stability plays in attracting foreign investors. Finally, we fail to find evidence of the impact of the global financial crises of 2008-09 on the inward FDI to SSA except for the SADC where it appears to have resulted into an increased inflow of FDI to the region.

The other regions exhibit insignificant effect of the same perhaps because their economies are not much globalized.

\subsection{Robustness Checks}

All our panel regressions are based on the Fixed Effects estimator with country-fixed effects and robust standard errors. We carry out robustness checks to find out the sensitivity of our regressions to the use of other alternative estimation techniques. Two other methods that allow estimation in the presence of AR (1) autocorrelation within cross-sectional correlation and heteroskedasticity across panels are applied as robustness checks and for comparison purposes with previous studies that have made use of the same (e.g. Anyanwu, 2011). These are the robust pooled ordinary least squares (OLS) and the robust maximum likelihood optimization of the generalized linear model (GLM). Additionally, our results are not substantially affected by the use of difference GMM suggested by Arellano and Bond (1991) and used in some other literature (e.g. Gammoudi and Cherif, 2015). To spare space, the results are not shown in the paper since they are similar to what we have presented already in the Tables but are available on request.

\section{Summary and Conclusions}

The most outstanding finding is that institutional quality matters for FDI inflows but this nexus may further be influenced by trade and capital account liberalization as well as financial deepening. While for the EAC and ECOWAS, financial development and capital account liberalization seem to matter more than trade openness in influencing the contribution of good institutions to inward FDI, for the SADC group, institutions appear to gain more from trade and less from capital account openness just as the ECCAS group benefits more from trade and less from financial deepening. The question as to what appropriate policies should be promoted in a heterogeneous SSA depends on the particular regional grouping. We advocate for comprehensive reforms to 
improve all the institutional indicators in general. Similarly, efforts to fully embrace regional integration to expand market for the products deserve maximum support. On the other hand there is need to integrate domestic financial systems into global financial markets to attract FDI inflows. Caution is however needed when designing strategies to encourage capital account liberalization in these regions since there is likelihood that they could be detrimental to inward FDI. Complementary policies to improve infrastructures and to encourage quality population, urbanization and a stable macro-economy are likely to yield better outcomes regarding inward FDI in SSA. Since the drivers of inward FDI appear to vary by region, a one-size-fits-all-policy is not likely to bear better outcomes. A "blanket" policy or policies designed for a "homogeneous" SSA might suffer from the fallacy of generalization and therefore perform counter to any sustainable development agenda.

The current study opens further research avenues into other areas. For example, our conclusion that institutions matter for FDI inflows would perhaps require a further dig-up of what in turn determines institutions, a subject beyond our coverage. Likewise, as result of the foregoing findings, one would wonder whether developed countries would exhibit similar behavior. We leave this for a future study.

\section{Acknowledgments}

The authors wish to thank Professor Dr. Michael Landesmann and Professor Dr. Joseph Francois of Johannes Kepler University Linz for the valuable professional comments. In addition, comments received from anonymous reviewers are much acknowledged.

\section{References}

Abdulla, A. R., Othman, M. M., \& Hongzhong, Z. (2012). An Empirical Study on the Strategies to Attract Foreign Direct Investments in Tanzania. RISUS, São Paulo, 3(1), 43-52.

Akramov, K. T. (2012). Foreign Aid Allocation, Governance, and Economic Growth. Philadelphia: University of Pennsylvania Press. http://dx.doi.org/10.9783/9780812207736

Alfaro, L., Chandab, A., Kalemli-Ozcanc, S., \& Sayekd, S. (2004). FDI and economic growth: the role of local financial markets. Journal of International Economics, 64, 89-112. http://dx.doi.org/10.1016/S0022-1996(03)00081-3

Anyanwu, J. C. (2011). Determinants of Foreign Direct Investment Inflows to Africa, 1980- 2007. African Development Bank Group Working Paper Series, No. 136.

Anyanwu, J. C. (2012). Why Does Foreign Direct Investment Go Where It Goes?: New Evidence From African Countries. Annals of Economics and Finance, 13-2, 433-470.

Arellano, M., \& Bond, S. (1991). Some tests of specification for panel data: Monte Carlo evidence and an application to employment equations. Review of Economic Studies, 58, 277-297. http://dx.doi.org/10.2307/2297968

Asiedu, E. (2002). On the Determinants of Foreign Direct Investment to Developing Countries: Is Africa Different? World Development, 30(1), 107-19. http://dx.doi.org/10.1016/S0305-750X(01)00100-0

Asiedu, E. (2006). Foreign Direct Investment in Africa: The Role of Natural Resources, Market Size, Government Policy, Institutions and Political Instability. The World Economy, 29(1), 63-77. http://dx.doi.org/10.1111/j.1467-9701.2006.00758.x

Asiedu, E., \& Lien, D. (2004). Capital Controls and Foreign Direct Investment. World Development, 32(3), 479490. http://dx.doi.org/10.1016/j.worlddev.2003.06.016

Baltagi, B. H. (2001). Econometric Analysis of Panel Data (2nd ed.). New York: John Wiley \& Sons.

Blundell, R., \& Bond, S. (1998). Initial Conditions and Moment Restrictions in Dynamic Panel Data Models. Journal of Econometrics, 87(1), 115-143. http://dx.doi.org/10.1016/S0304-4076(98)00009-8

Bun, M. J. G., \& Kiviet, J. F. (2006). The effects of dynamic feedbacks on LS and MM estimator accuracy in panel data models. Journal of Econometrics, 132(2), 409-444. http://dx.doi.org/10.1016/j.jeconom.2005.02.006

Bun, M. J. G., \& Windmeijer, F. (2010). The weak instrument problem of the system GMM estimator in dynamic panel data models. Econometrics Journal, Royal Economic Society, 13(1), 95-126. http://dx.doi.org/10.1111/j.1368-423x.2009.00299.x

Chinn, M. D., \& Ito, H. (2006). What Matters for Financial Development? Capital Controls, Institutions, and $\begin{array}{lllll}\text { Interactions. Journal of Development } & \text { Economics, } & \text { 81(1), }\end{array}$ 
http://dx.doi.org/10.1016/j.jdeveco.2005.05.010

Dasgupta, D., \& Ratha, D. (2000). What Factors appear to Drive Capital Flows to Developing Countries? And How does Official Lending Respond? Policy Research Working Paper, WPS 2392, World Bank, Washington DC.

Dunning, J. H. (1977). Trade, location of economic activity and the MNE: a search for an eclectic approach. In B. Ohlin, \& P. O. Hesselborn (Eds.), The International Allocation of Economic Activity (pp. 395-418). London, Macmillan. http://dx.doi.org/10.1007/978-1-349-03196-2_38

Dunning, J. H. (1988). The Eclectic Paradigm of International Production: A restatement and some possible extensions. Journal of International Business Studies, 19(1), 1-31. http://dx.doi.org/10.1057/palgrave.jibs.8490372

Fernandez-Arias, E., \& Hausmann, R. (2000). Foreign Direct Investment: Good Cholesterol? Inter-American Development Bank Research Department Working Paper, No. 417.

Gammoudi, M., \& Cherif, M. (2015). Capital Account Openness, Political Institutions and FDI in the MENA Region: An Empirical Investigation. Discussion Paper No. 2015-10, Kiel Institute for the World Economy. http://www.economicsejournal.org/economics/discussionpapers/2015-10.

Gani, A. (2007). Governance and Foreign Direct Investment Links: Evidence from Panel Data Estimations. Applied Economics Letters, 14(10), 753-756. http://dx.doi.org/10.1080/13504850600592598

Ghosh, M., Syntetos, P., \& Wang, W. (2012). Impact of Restrictions on Inward FDI in OECD Countries. Global Economy Journal, 12(3). http://dx.doi.org/10.1515/1524-5861.1822

Grünfeld, L. A., \& Svindal, L. C. (2000). Patterns of Trade and Foreign Direct Investment in Africa. Working Paper No. 607, Norsk Utenrikspolitisk Institutt Oslo.

Holtz-Eakin, D., Newey, W., \& Rosen, H. S. (1988). Estimating vector autoregressions with panel data. Econometrica, 56, 1371-1395. http://dx.doi.org/10.2307/1913103

Kaufmann, D., Kraay, A., \& Mastruzzi, M. (2011). Governance Matters: Aggregate and Individual Governance Indicators. World Bank Policy Research Working. Retrieved from http://info.worldbank.org/governance/wgi/index.asp

Kim, H. (2010). Political Stability and Foreign Direct Investment. International Journal of Economics and Finance, 2(3), 59-71. http://dx.doi.org/10.5539/ijef.v2n3p59

Kinda, T. (2010). Investment Climate and FDI in Developing Countries: Firm-Level Evidence. World Development, 38(4), 498-513. http://dx.doi.org/10.1016/j.worlddev.2009.12.001

Kose, M. A., Rogoff, K., Prasad, E., \& Wei, S.-J. (2003). Effects of Financial Globalization on Developing Countries: Some Empirical Evidence. IMF Occasional Papers 220, International Monetary Fund. http://dx.doi.org/10.5089/9781589062214.084

Leitao, N. C. (2010). Localization Factors and Inward Foreign Direct Investment in Greece. Theoretical and Applied Economics, 6(547), 17-26.

Mundell, R. (1957). International Trade and Factor Mobility. American Economic Review, 47, 321-335.

North, D. (1990). Institutions, Institutional Change and Economic Performance. Cambridge: Cambridge University Press. http://dx.doi.org/10.1017/CBO9780511808678

Noy, I., \& Vu, T. B. (2007). Capital Account Liberalization and Foreign Direct Investment. The North American Journal of Economics and Finance, 18(2), 175-194. http://dx.doi.org/10.1016/j.najef.2007.04.001

Onyeiwu, S., \& Hemanta, S. (2004). Determinants of Foreign Direct Investment. Journal of Developing Societies, 20(1), 89-106. http://dx.doi.org/10.1177/0169796X04048305

Roodman, D. (2009a). A Note on the Theme of Too Many Instruments. Oxford Bulletin of Economics and Statistics, Department of Economics, University of Oxford, 71(1), 135-158, 02.

Roodman, D. (2009b). How to do xtabond2: An introduction to difference and system GMM in Stata. Stata Journal, StataCorp LP, 9(1), 86-136.

Seetanah, B., \& Khadaroo, A. J. (2007). Foreign Direct Investment and Growth: New Evidences from Sub-Saharan African Countries. Paper Presented at Economic Development in Africa, CSAE Conference.

United Nations. (2010). FDI in Africa. Policy Brief No.4, October 2010. Retrieved from 
http://www.nepad.org/system/files/Layout_FDInew.pdf

World Investment Report. (2014). Investing in a Low-Carbon Economy. Retrieved from http://unctad.org/en/Docs/wir2010_en.pdf

\section{Copyrights}

Copyright for this article is retained by the author(s), with first publication rights granted to the journal.

This is an open-access article distributed under the terms and conditions of the Creative Commons Attribution license (http://creativecommons.org/licenses/by/4.0/). 